Journal of Advanced College of Engineering and Management, Vol. 6, 2021

\title{
STUDY ON PARAMETRIC ANALYSIS OF PILED RAFT FOUNDATION SYSTEM USING FINITE ELEMENT APPROACH
}

\author{
Santosh Niraula ${ }^{1}$, Dr. Indra Prasad Acharya ${ }^{2}$ \\ ${ }^{1}$ Research Student, Masters in Geotechnical Engineering, Pulchowk Campus \\ Email Address: santosh.niraula@acem.edu.np \\ ${ }^{2}$ Associate Professor, Coordinator, Master Program in Geotechnical Engineering, Pulchowk Campus, TU
}

\begin{abstract}
To accommodate the shear requirement and settlement requirement of high rise construction, the concept of piled-raft foundation has been developed. This research deals with successive analysis of parameters of piled-raft foundation system using PLAXIS2D as a FEM tool. Plain strain analysis of piled raft foundation system has been conducted out by successive fixing up of parameters. For the analysis two cases has been studied for piled-raft lying on silty soil deposit and on clayey deposit with respect to uniform static loading from superstructure. The result of successive variation of parameters showed that variation has limiting effect on stress and displacement behavior. The analysis is also performed for raft of different relative stiffness and pile of different relative compressibility and load sharing between plain strain pile and raft has been analyzed.
\end{abstract}

Keywords: Piled-raft, Finite Element Method, Parametric analysis, PLAXIS-2D

\section{Introduction}

The present scenario of high rate of urbanization and limitation of space lead to development of high rise construction. For development of such structures on Kathmandu valley, which rests on soft soil is mainly affected by differential settlement. To prevent excessive settlements, pile foundation have been developed and widely used in recent decades. However design of foundation system considering only single type of foundation; either pile or raft is not a feasible solution because of load sharing mechanism of pile-raft-soil. Therefore, the combination of separate systems, namely "Piled Raft Foundation" has been developed [1].

The pile raft foundation system comprises of composite structure of piles and raft where raft acts as pile cap. Raft interacts with the underlying soil and supported by number of piles. The combined assembly is then subjected to vertical and lateral loadings. These loads are transferred to the soil through raft and the piles. Piles raft foundation system is designed for sharing of load between piles and raft apart from conventional piled or raft foundation where, only piles are used for reducing total and differential settlements and contribution of raft is disregarded. In piled raft system piles primarily acts as settlement reducers and load sharing between pile and raft is the secondary issue. The total and differential settlement which is major aspect for the piled raft system can be brought within permissible limits by using various arrangements such as number of piles, diameter of piles, spacing of piles, length of piles and thickness of raft etc.

The main aim of this research is to study the settlement and load sharing mechanism of piled raft foundation under variable condition of parameters. For the reason two cases in clayey silt type of soil and highly clayey soil of high plasticity has been considered. Plaxis2D is used as a tool for analyzing the piled raft foundation.

\section{Literature Review}

Literature review cover these three fundamental approaches, $1^{\text {st }}$ is to access the requirement of piling for raft foundation by computing bearing capacity of raft foundation, $2^{\text {nd }}$ is to discuss the approach of 
piled-raft foundation analysis and $3^{\text {rd }}$ is approach to modelling piled raft as plain strain problem in Plaxis2D.

\subsection{Bearing Capacity of Raft Foundation}

Different approaches for computing bearing capacity of raft foundation has been discussed by different researchers. Teng (1962) has provided an approach of computing bearing capacity on cohesionless soil deposit and Skempton (1951) has provided an approach to compute bearing capacity of raft foundation on clays. Further other different researchers Hansen (1970), Meyerhoff (1963) and Vesics $(1973,1974)$ has provided approach to calculate bearing capacity of raft foundation. All this approach is compiled in [2].

\subsection{Methods of Analysis of Piled raft foundation.}

(Poulos, 2001)[3] categorized the methods of analysis of piled raft foundations into three classes;

Simplified calculation methods, Approximate computer-based methods and more rigorous computerbased methods.

Some of the simplified methods are those of (Randolph,1994)[4] and (Burland,1995)[5].

In (Randolph's, 1994) approach, only the interaction between the piles and the raft is taken into account with the factor of $\square \mathrm{cp}$ and the interaction between piles in the pile group is not considered. This may be because of the consideration of the non-linearity of the soil has relatively small effect on pile group response. For the components of pile group and raft, (Randolph, 1983) in (Randolph, 1994) relates the settlements by tagging subscripts of $\mathrm{p}$ for the pile group and $\mathrm{r}$ for the raft as;

$\left\{\begin{array}{l}w_{p} \\ w_{r}\end{array}\right\}=\left[\begin{array}{cc}\frac{1}{k_{p}} & \frac{\alpha_{p r}}{k_{r}} \\ \frac{\alpha_{r p}}{k_{p}} & \frac{1}{k_{r}}\end{array}\right]\left\{\begin{array}{l}P_{p} \\ P_{r}\end{array}\right\}$ Where $\alpha_{p r}$ and $\alpha_{r p}$ are the interaction factors, $P$ and $k$ are the loads and stiffness. By Maxwell's Reciprocal Theorem (diagonal terms are equal) and considering the equality of the average settlement of raft and pile group, overall stiffness kpr and the proportion of load carried by the raft $\mathrm{X}$ are calculated as;

$k_{p r}=\frac{k_{p}+k_{r}\left(1-2 \alpha_{r p}\right)}{1-\alpha_{r p}^{2}\left(\frac{k_{r}}{k_{p}}\right)}$ Where, $k_{p}$ the stiffness of the pile group and the raft $k_{r}$ can be calculated by the elastic theory using the methods of equivalent pier and Fraser \& Wardle (1976)[6] respectively.

$X=\frac{P_{r}}{P_{t}}=\frac{P_{r}}{P_{r}+P_{p}}=\frac{\left(1-\alpha_{r p}\right) k_{r}}{k_{p}+\left(1-2 \alpha_{r p}\right) k_{r}}$

The load carried by the raft is Pr and the total load is Pt. is the raft-pile interaction factor and approximated by Randolph (1983) for single piles, which may be used for the large groups with an equivalent radius rc, with circular caps;

$\alpha_{r p}=1-\frac{\ln \left(\frac{r_{c}}{r_{0}}\right)}{\zeta}$ Where, $r_{c}=$ average radius of pile cap, $r_{0}=$ radius of pile

$\zeta=\ln \left(\frac{r_{m}}{r_{0}}\right) r_{m}=\{0.25+\xi[2.5 \rho(1-v)-0.25] * L\}$

$\xi=\frac{E_{s l}}{E_{s b}} \rho=\frac{E_{s a v}}{E_{s l}}, L=$ length of pile, $E_{s l}=$ Young's modulus of soil at level of pile tip, $E_{s b}=$ Young's modulus of soil at bearing stratum below pile tip $E_{s a v}=$ average Young's modulus of soil along pile shaft

Randolph (1994) reported that the raft-pile interaction factor $\square \mathrm{rp}$ has a tendency to be equal to 0.8 for large group of piles, even for $6 \times 6$ pile groups. Therefore, the overall stiffness kpr may be simplified to; 
$k_{p r}=\frac{1-0.6\left(\frac{k_{r}}{k_{p}}\right)}{1-0.64\left(\frac{k_{r}}{k_{p}}\right)} k_{p}$ and the proportion of load carried by the raft $P_{r}$ over load carried by the pile group

$P_{p}$

$\frac{P_{r}}{P_{p}}=\frac{0.2 k_{r}}{1-0.8\left(\frac{k_{r}}{k_{p}}\right) k_{p}}$

(Burland, 1995) considered the piles as settlement reducers, and suggested that, if the piles are located below the columns, excess load Psu corresponding the difference of the design load and the load P0 carried by the raft P1, is equal to the fully mobilized shaft resistance of these piles times a mobilization factor of 0.9 . Therefore, foundation can be analyzed as a raft, which only subjected to the reduced load Qr.

$Q_{r}=Q-0.9 P_{s u}$

For the estimation of settlement, (Poulos, 2001) suggested an adaptation for the (Randolph's, 1994) approach as;

$S_{p r}=\frac{S_{r} * k_{r}}{k_{p r}}$ Where, $S_{p r}=$ settlement of the piled raft,$S_{r}=$ settlement of the raft without piles under the total load,$k_{r}=$ stiffness of the raft,$k_{p r}=$ stiffness of piled raft

\section{Approximate computer-based methods}

The approximate computer-based methods are based on elastic theory and mainly have two approaches (Poulos, 2001) as; strip on springs and plate on springs. In these approaches, the raft is treated as a strip and as a thin plate respectively. Additionally, piles are treated as springs and the soil as an elastic continuum, which are also simplified into springs, for the foundation-structure interaction analyses. Furthermore, the combination of these two methods is also possible.

\section{More rigorous computer-based methods}

More rigorous methods mainly include boundary element methods and finite element methods. Besides, for the different members of the foundation, combination of these methods has been applied.

\subsection{Plane strain FEM-model for piled rafts}

The main problem when modelling a piled raft with a plane strain model is the transition from three to two dimensions, i.e. to express a three dimensional problem in a two dimensional model. To do this the "out off"-plane rows of piles are simplified as wall elements, called plane strain piles as shown in Fig 1.

The wall element is defined per meter; the normal stiffness, bending stiffness and weight for the piles in the "out off"-plane row of piles are therefore "smeared" per meter.

$E A_{p s p}=E A_{p} \frac{n_{p-r o w-i}}{L_{r}}$ Where, $E A_{p s p}=$ normal stiffness of plain strain piles. $E A_{p}=$ normal stiffness of one pile, $n_{p-\text { row- }}=$ number of piles in row $i$ and $L_{r}=$ raft length in plane.

Analogously bending stiffness is inputted as;

$E I_{p s p}=E I_{p} \frac{n_{p-r o w-i}}{L_{r}}$ and the weight as $W_{p s p}=W_{p} \frac{n_{p-r o w-i}}{L_{r}}$ 


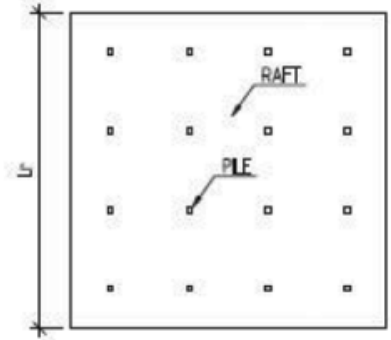

PLEED RAFT

Fig 1 Plain strain model of piled rafts

The change of cross section when introducing the plane strain piles involves a change in periphery area, which will affect the important shaft resistance and an equivalent shaft resistance is therefore introduced. Since a plane strain pile has a periphery defined by its two sides, the shaft resistance is modified to

$f_{\text {shaft }, e q}=\frac{n_{p-\text { row }-i} A_{s} f_{\text {shaft }}}{2 L_{r}}=\alpha_{\text {ar }} f_{\text {shaft }}$ Where, $f_{\text {shaft,eq }}=$ the friction strength at the interface between the soil and the shaft for plain strain piles, $A_{s}=$ shaft area per unit depth, $\square_{a r}=$ area ratio.

In Plaxis the plane strain piles are modelled by using plate elements with corresponding interface elements, where, the interface elements describe the interaction between the pile and the soil. This element is used to model the shaft resistance. However, the interface element has the strength properties of the surrounding soil multiplied by a factor, called Rinter(i.e. strength reducing factor for interface). The shaft resistance is modified according to above mentioned equation by reducing the strength of the adjacent soil with the strength reducing factor, i.e. $R_{\text {inter }, e q}=\alpha_{a r} R_{\text {inter }}=\frac{n_{p-r o w-i A_{s}}}{2 L_{r}}$

Plaxis is Dutch company developing software, with the same name, that is using the finite element method (FEM) for modeling of geotechnical problems. The software portfolio includes two and three dimensional simulation of soil and soil-structure interaction. Plaxis governs three main theories in its FEM-code; deformation, groundwater flow and consolidation. Additional, there is an extensionprogram for dynamic calculations.[7]

Similar plane strain models were examined by (PoulosH.G.,2001), by comparing it to other analysis method for simple examples. The comparison showed that the plane strain models, may lead to overestimation of the settlement and the pile force.

\section{Methodology}

For the analysis of piled raft foundation, two sites were selected. Site I represents the soil data from Madaha River whereas Site II represent soil data from premises of Pulchowk campus. Soil type from site I represent highly plastic clay whereas soil is classified as clayey silt in case of site II.

Grain size distribution shows that for Site I, up to depth of $7.5 \mathrm{~m}$, soil type is sandy soil and after it the soil type is clay of high plasticity. Only property of highly clayey soil is considered for analysis. For site II most of the soil particles were of silt size i.e. between $0.06 \mathrm{~mm}$ to $0.002 \mathrm{~mm}$ and identified as clayey silt.

Superstructure is modelled as a five storied building resting on rectangular raft of size $40 \mathrm{~m} \mathrm{X} 22.5 \mathrm{~m}$. The load from superstructure is assumed to be distributed uniformly over the entire raft. The load calculation is determined from SAP analysis. 
The numerical analysis has been done by finite element using Plaxis2DV.8.2. The analysis process for piled rafts in this study involves four stages. A preliminary stage was to assess the required raft thickness. A second stage was done to assess the required pile configuration for the piled raft system. Third stage was to obtain the optimum pile length and final step is to optimize pile width. For each step previously fixed parameter is kept constant. As an example for optimizing pile diameter, raft thickness, pile configuration and pile length are kept fixed. For optimizing each parameter, trend of total settlement of system, differential settlement of system, load carried by piles and maximum bending moment on raft has been analyzed.

\section{i. Geotechnical and material parameters for input}

Table 1 Soil parameters used for Plaxis modelling for Site I.

\begin{tabular}{|c|c|c|c|c|c|}
\cline { 1 - 5 } Soil parameters & \multicolumn{6}{|l|}{} \\
\hline General & Description & Parameters & Description & Interface & Description \\
\hline Identification & Clay & Es & $2933 \mathrm{kN} / \mathrm{m}^{2}$ & $\mathrm{R}_{\text {inter }}$ & 0.7 \\
\hline Material model & Mohr-columb & $\square$ & 0.4 & & \\
\hline Material type & Drained & $\mathrm{c}$ & $12 \mathrm{kN} / \mathrm{m}^{2}$ & & \\
\hline$\square_{\text {unsat }}$ & $16.5 \mathrm{kN} / \mathrm{m}^{3}$ & $\square$ & $22^{\circ}$ & & \\
\hline$\square_{\text {sat }}$ & $19.2 \mathrm{kN} / \mathrm{m}^{3}$ & $\square$ & - & & \\
\hline $\mathrm{K}_{\mathrm{x}}$ & $1 \mathrm{~m} / \mathrm{day}$ & & & & \\
\hline $\mathrm{K}_{\mathrm{y}}$ & $1 \mathrm{~m} /$ day & & & & \\
\hline $\mathrm{e}_{\mathrm{int}}$ & - & & & & \\
\hline
\end{tabular}

Table 2 Soil Parameters used for in Plaxis2D for site II

\begin{tabular}{|c|c|c|c|c|c|}
\hline \multicolumn{7}{|c|}{ Soil parameters } \\
\hline General & Description & Parameters & Description & Interface & Description \\
\hline Identification & Clayey Silt & Es & $2850 \mathrm{kN} / \mathrm{m}^{2}$ & $\mathrm{R}_{\text {inter }}$ & 0.9 \\
\hline $\begin{array}{c}\text { Material } \\
\text { model }\end{array}$ & $\begin{array}{c}\text { Mohr- } \\
\text { columb }\end{array}$ & $\square$ & 0.33 & & \\
\hline Material type & Drained & $\mathrm{c}$ & $9 \mathrm{kN} / \mathrm{m}^{2}$ & & \\
\hline$\square_{\text {unsat }}$ & $17.6 \mathrm{kN} / \mathrm{m}^{3}$ & $\square$ & $32^{\circ}$ & & \\
\hline$\square_{\text {sat }}$ & $19 \mathrm{kN} / \mathrm{m}^{3}$ & $\square$ & - & & \\
\hline $\mathrm{K}_{\mathrm{x}}$ & $1 \mathrm{~m} /$ day & & & & \\
\hline $\mathrm{K}_{\mathrm{y}}$ & $1 \mathrm{~m} /$ day & & & & \\
\hline $\mathrm{e}_{\text {int }}$ & - & & & & \\
\hline
\end{tabular}

Table 3 Sample Material parameters for Raft element for thickness $1.2 \mathrm{~m}$ for site I.

\begin{tabular}{|c|c|}
\hline Raft parameters & Description or values \\
\hline Identification & Raft \\
\hline Material type & elastic \\
\hline
\end{tabular}




\begin{tabular}{|c|c|}
\hline Normal stiffness (EA) & $3.55 \mathrm{E} 7 \mathrm{kN} / \mathrm{m}$ \\
\hline Bending stiffness (EI) & $4.26 \mathrm{E} 6 \mathrm{kN} / \mathrm{m}^{2} / \mathrm{m}$ \\
\hline Thickness (d) & $1.2 \mathrm{~m}$ \\
\hline Weight (w) & $30 \mathrm{kN} / \mathrm{m} / \mathrm{m}$ \\
\hline Poisson's ratio ( $\square)$ & 0.2 \\
\hline
\end{tabular}

E, young modulus for raft is calculated according to raft of reinforced concrete of grade M35. So, $\mathrm{E}=5000(35)^{0.5}=29.58 \mathrm{E} 6 \mathrm{kN} / \mathrm{m}^{2}$

\section{Model for raft thickness optimization}

Model is presented in figure 2 where raft foundation is analyzed as plain strain problem. Raft of dimension $22.5 \mathrm{~m}$ was created on soil with dimension exceeding 1.5 times dimension of raft on either side of raft i.e. soil with dimension $90 \mathrm{~m} \times 70 \mathrm{~m}$ was created and in which $22.5 \mathrm{~m}$ of plate element representing raft is placed symmetrically from the center. The displacement are prescribed to zero in both $\mathrm{x}$ and $\mathrm{y}$ direction in the bottom and in $\mathrm{x}$ direction in sides. As per the research conducted by (John Sebastein, 2008)[8], FE analysis of piled and Piled raft foundations, it was showed that curve shows same trend for meshing with coarse, medium and fine mesh. But with fine mesh, it showed unphysical premature soil body collapsing. So medium dense type of meshing is done. The interface reduction factor is used as 0.9 for silty soil and 0.7 for clayey soil as per Plaxis is reference manual 15 node element is used for soil and plate element is used for raft. The material properties presented in table 1, 2 and 3 is used. The thickness of raft is varied from $0.2 \mathrm{~m}$ to $2 \mathrm{~m}$ in case of site I and $0.4 \mathrm{~m}$ to $1.4 \mathrm{~m}$ in case of site II for thickness optimization, also the raft input parameters varies. The sample calculation for raft thickness $1.2 \mathrm{~m}$ is as presented. The calculation was performed as plastic calculations and with standard setting for iterative procedure. Just one calculation phase was defined, including activation of all the elements and load.

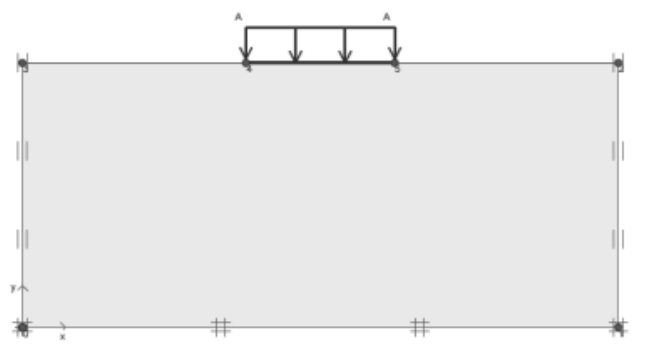

Fig 2 Model for raft thickness optimization in Plaxis

\section{ii. Model for pile configuration optimization}

In the second phase of the study, optimization of pile configuration was performed keeping the raft thickness as $1.2 \mathrm{~m}$ and $1 \mathrm{~m}$ respectively for site I and site II respectively. For the parametric study, the number of piles is varied from 1 to 10 maintaining equal spacing between piles in each variation of number. The length of pile is taken as $20 \mathrm{~m}$, width of pile is taken as $0.5 \mathrm{~m}$ and grade of concrete is used same as that of raft.

Table 4Input parameters for pile

\begin{tabular}{|c|c|}
\hline Pile parameters & Description or values \\
\hline Identification & pile \\
\hline Material type & elastic \\
\hline
\end{tabular}




\begin{tabular}{|c|c|}
\hline Normal stiffness (EA) & $328671.1 \mathrm{kN} / \mathrm{m}$ \\
\hline Bending stiffness (EI) & $6847.315 \mathrm{kN} / \mathrm{m}^{2} / \mathrm{m}$ \\
\hline Weight (w) & $0.278 \mathrm{kN} / \mathrm{m}$ \\
\hline Poisson's ratio ( $\square$ ) & 0.2 \\
\hline
\end{tabular}

Then medium dense type of meshing is done and redefined around the corners of the structured. Interface elements are drawn beneath the piles to smoothen the mesh.

The initial stress state was calculated with $\mathrm{K}_{0}$ procedure. For this calculation no element were activated.

The calculation was performed as plastic calculations and with standard setting for iterative procedure. Just one calculation phase was defined, including activation of all the elements and load.

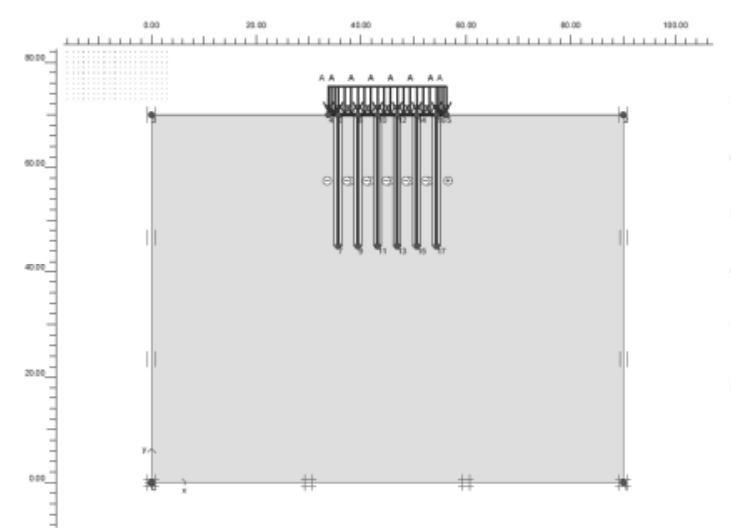

Fig 3 Pile configuration optimization model

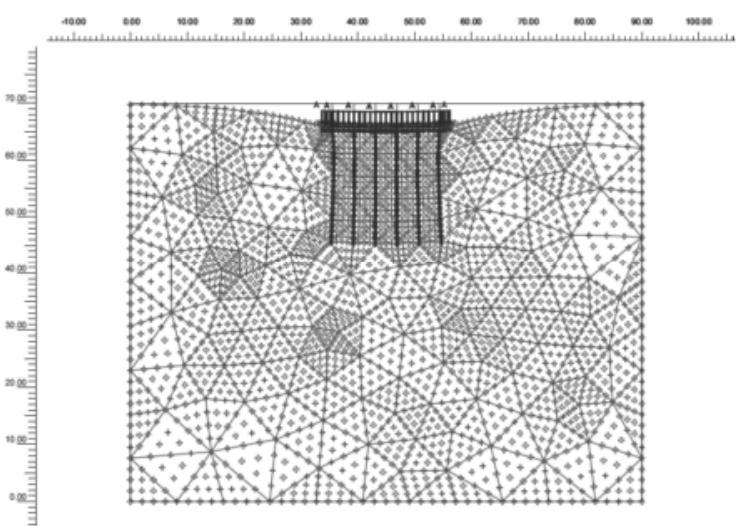

Fig 4 Deformed Mesh

The maximum normal forces which is situated in upper portion of piles is used to calculate the load shared by piles.

Load shared by the piles $=\frac{\text { loadcarriedbythepiles }}{\text { totalload }}=\frac{\text { Laxialforce }}{\left(q+w_{\text {raft }}\right) L_{r}+n_{p} w_{p, e q} L_{r}}$

\section{iii. $\quad$ Pile Length Optimization}

Based on the analysis of trend of total displacement, differential displacement, maximum bending moment of raft and load shared by piles for different configuration, pile number with 6 number of pile is selected. For 6 number of piles with equal spacing between them, now pile length are varied from $5 \mathrm{~m}$ to $45 \mathrm{~m}$ at interval of 5 with fixed raft thickness of $1.2 \mathrm{~m}$ for site I and $1 \mathrm{~m}$ for site II and pile width of $0.5 \mathrm{~m}$. Further same curves for total displacement, differential displacement, maximum BM of raft and load shared by piles are generated and analyzed for fixing up of pile length.

\section{iv. Pile Width Optimization}

Fixing raft thickness, pile configuration and pile length simultaneously, now pile width is varied from $0.25 \mathrm{~m}$ to $3.75 \mathrm{~m}$ in case of site I and 0.1 to $2 \mathrm{~m}$ in case of site II. Curves are generated for total displacement, differential displacement, pile load sharing and Maximum bending moment on raft versus pile width.

\section{Results}

At the 1st stage of work an attempt has done to optimize the thickness of raft for the design of piled raft foundation system by only considering raft foundation during which thickness of raft is varied 
from $0.2 \mathrm{~m}$ to $2 \mathrm{~m}$ for site I and $0.4 \mathrm{~m}$ to $1.4 \mathrm{~m}$ for site II and total settlement, differential settlement, variation of maximum bending moment of raft is obtained.

In the second stage of the study, optimization of pile configuration was performed keeping the raft thickness as $1.2 \mathrm{~m}$ and $1 \mathrm{~m}$ respectively for site I and site II. For the parametric study, the number of piles is varied from 1 to 10 maintaining equal spacing between piles in each variation of number. The length of pile is taken as $20 \mathrm{~m}$, width of pile is taken as $0.5 \mathrm{~m}$ and grade of concrete is used same as that of raft for site I. In case of site II, baring stratum is defined by fixing up the pile at lower end and trend of variation of stress and settlement parameters is studied.

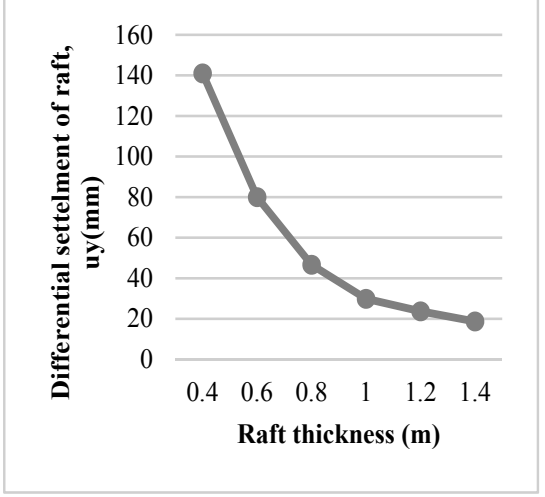

Figure 5Raft thickness (t) vs. Differential Settlement $\left(\mathrm{u}_{\mathrm{y}}\right)$. For Site II

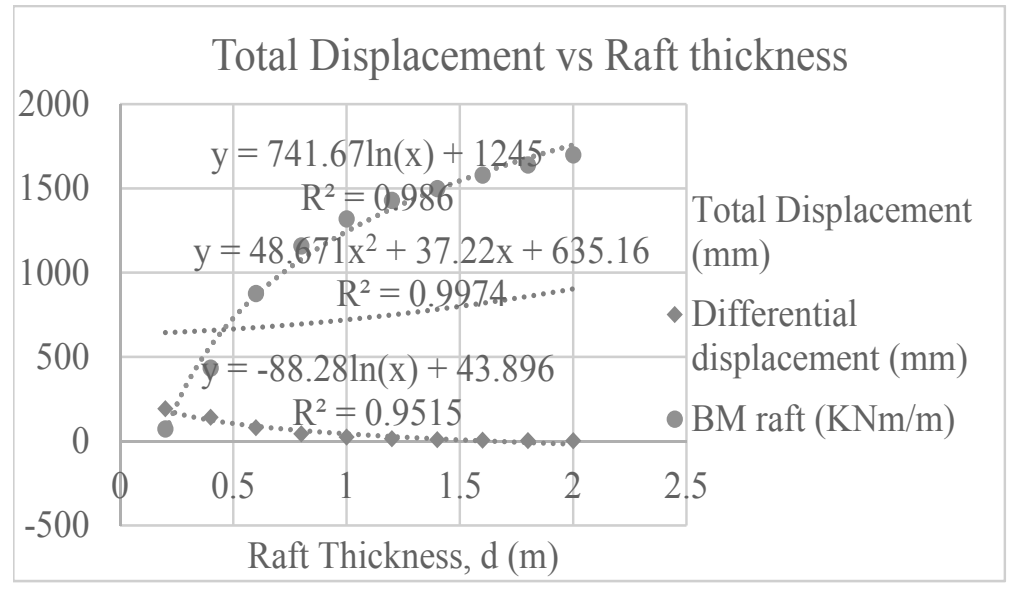

Figure 6 Displacement trend and Bending moment of raft foundation

In the third stage based on the curves generated in stage 2 and taking the curve for displacement as primary governing criteria and other as secondary, the raft having 6 number of pies equally spaced from center is selected. For the configuration, now length of pile are varied from $5 \mathrm{~m}$ to $45 \mathrm{~m}$ and corresponding variation of stress and displacement parameters with respect to pile length has been obtained for site I and site II. The curves obtained are shown in figure 12 and 14.

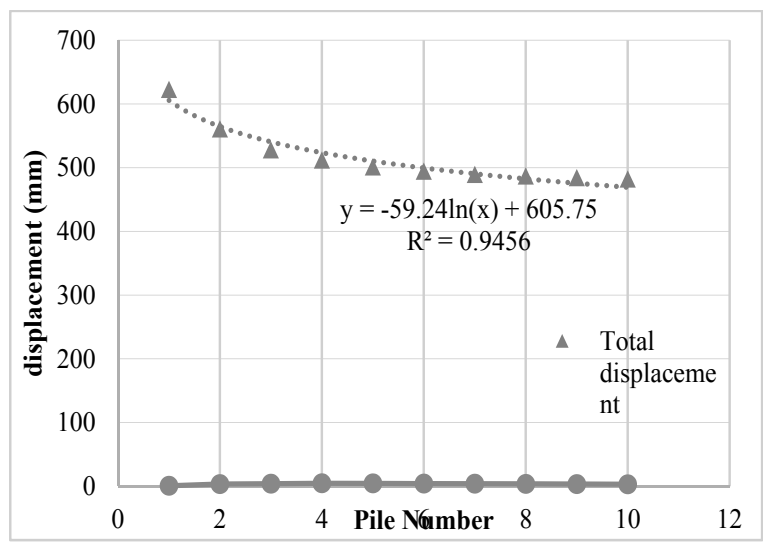

Figure 7 Total and Differential displacement vs. Pile Number for site I

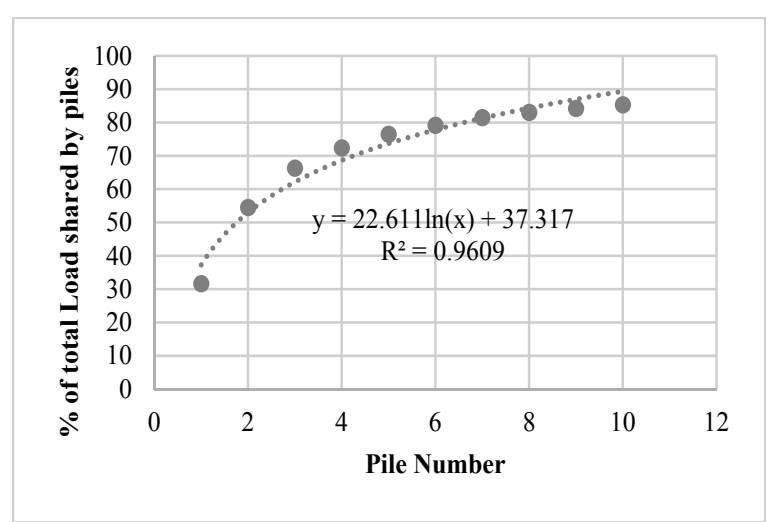

Figure $8 \%$ load shared by piles vs. Pile number for site I

For site II, two types of pile analysis has been carried, one for relatively compressible pile and other for rigid pile. The trend of variation of stress and displacement parameters has been obtained and presented in figure 15 to figure 17. 
It is evident from the curves obtained in stage 3 that stiffness of foundation governs the displacement and stress parameter of foundation system. In 4th stage of study, pile width is varied for 6 number of piles and pile length as $20 \mathrm{~m}$ which is optimized based on displacement criteria as governing criteria. The variation of width is performed from $0.25 \mathrm{~m}$ to $3.75 \mathrm{~m}$ at an interval of $0.25 \mathrm{~m}$. Maximum width of pile is limited by IS code that minimum spacing between pile should be twice its width or diameter. For the variation of width, further displacement and stress parameters variation with respect to pile width has been generated and is presented in Figure 19 to Figure 21.
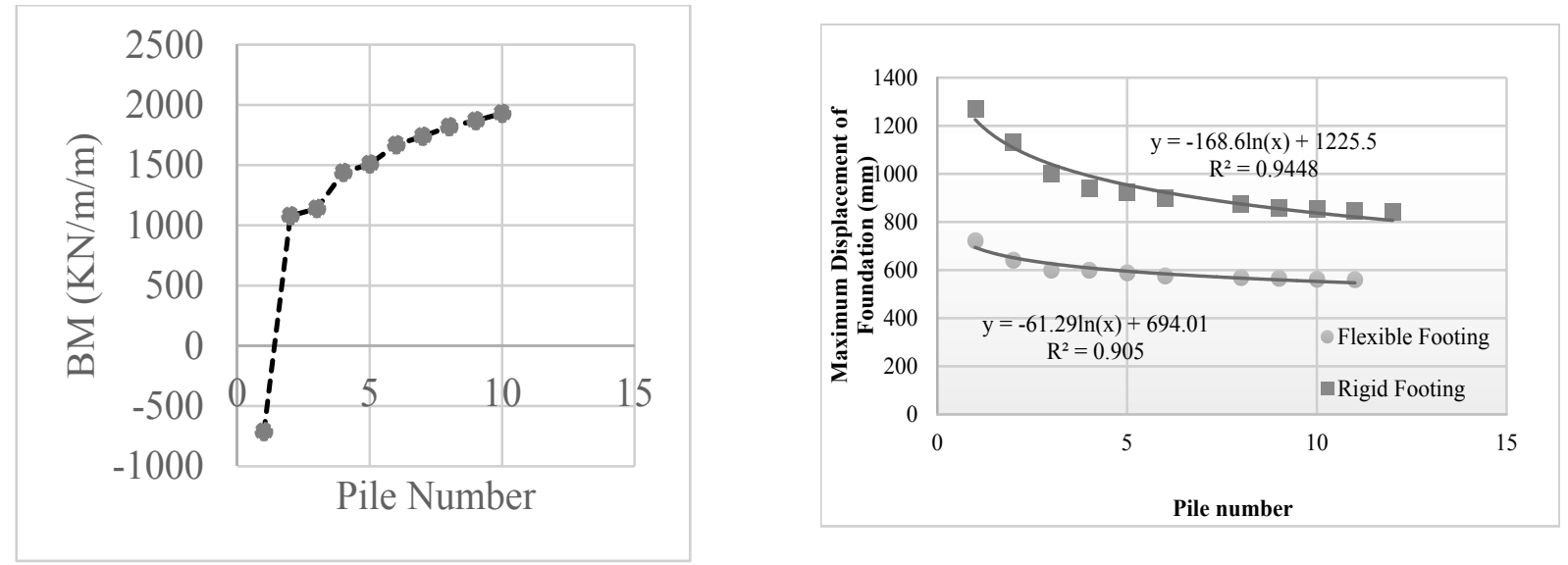

Fig 9 Raft BM vs. Pile Number for site I

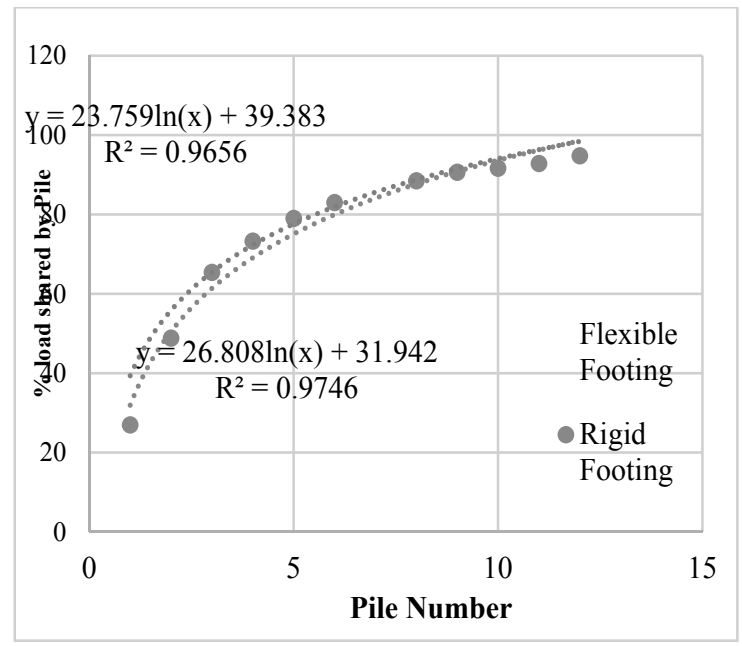

Fig 10 Pile load sharing versus pile number for site II

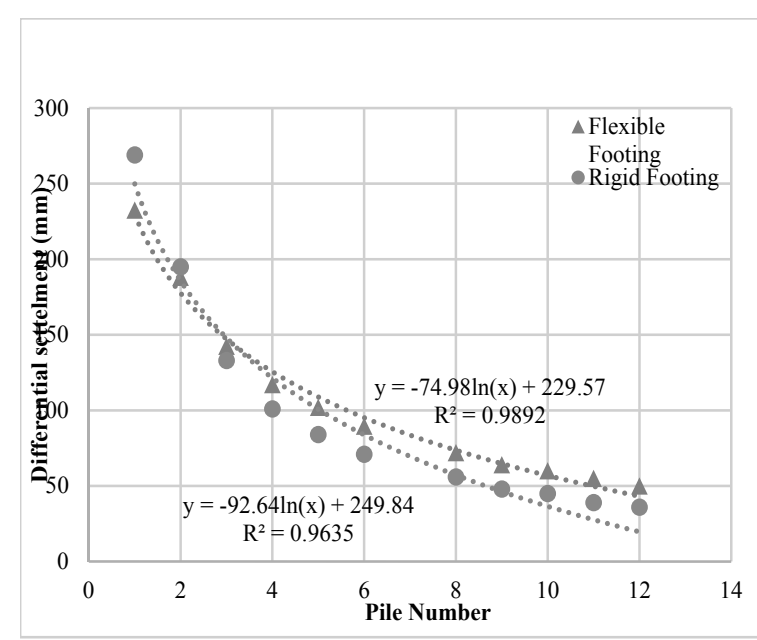

Fig 11 Differential settlement vs. Pile number for site II

\section{Verification}

As piled raft phenomena is not two dimensional, the theoretical approach discussed in literature review could not be used for verification. So the tends obtained in different stage of research is validated graphically by approach provided by (P.T. Brown and T.J. Wiesner, 1975)[9] has been used. In the paper graphical result are presented for load taken by piles, maximum displacement, differential displacement and maximum bending moment due to uniformly distributed load to strip footing supported by piles. The paper presents an attempt to provide parametric study of the problem 
including the effect of pile and footing stiffness. The stiffness of strip is indicated by Kst, and the compressibility of pile is indicated by Kp.

Where, $K_{s t}=\frac{16 E I\left(1-v_{s}^{2}\right)}{\pi E_{s} L^{4}}$ As per Paulos and Mattes (1973) and $K_{p}=\frac{E_{p}}{E_{s}}$ as used by Brown (1969).

When $K_{p}=100$, the pile is comparatively compressible and when $K_{p}=1000$, the pile is regarded as stiff. The values of $\mathrm{K}_{\mathrm{st}}<0.001$ indicates flexible strip whereas $\mathrm{K}_{\mathrm{st}}>0.1$ is considered as stiff.

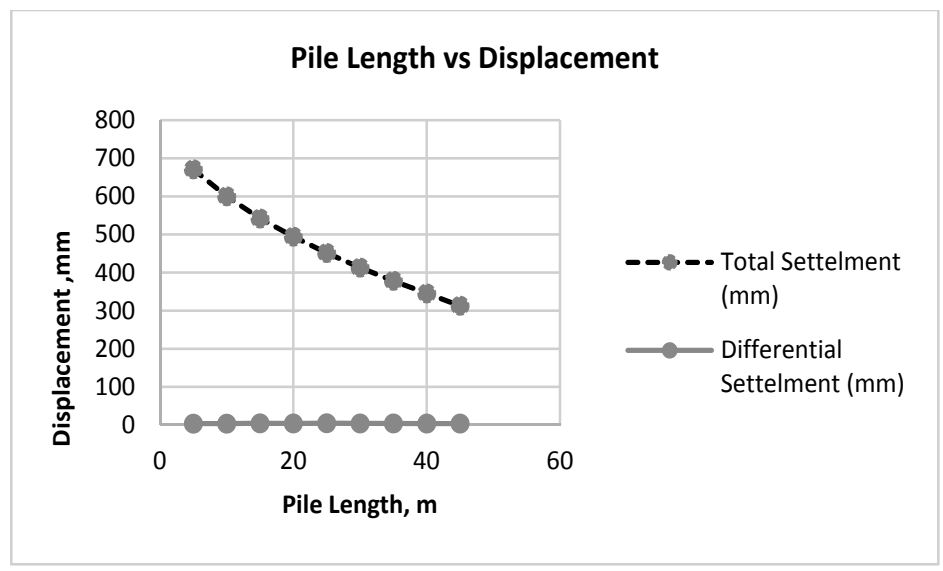

Fig 12 Displacement vs. pile length for site I

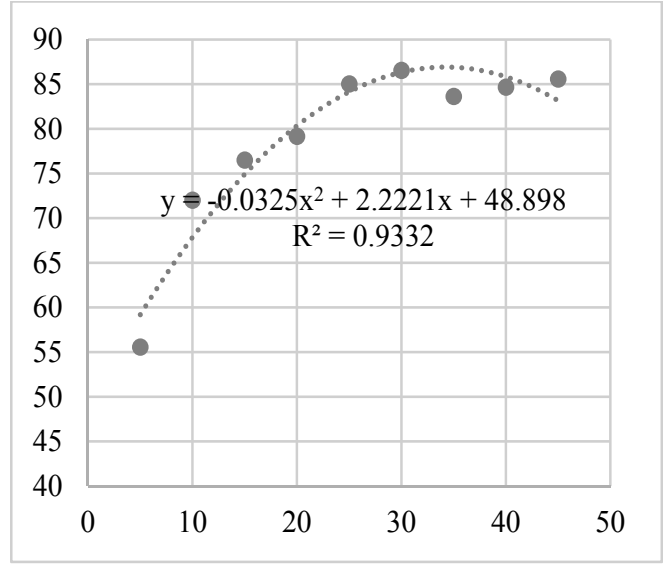

Fig 13 Percentage of total load carried by piles vs. pile length for site I

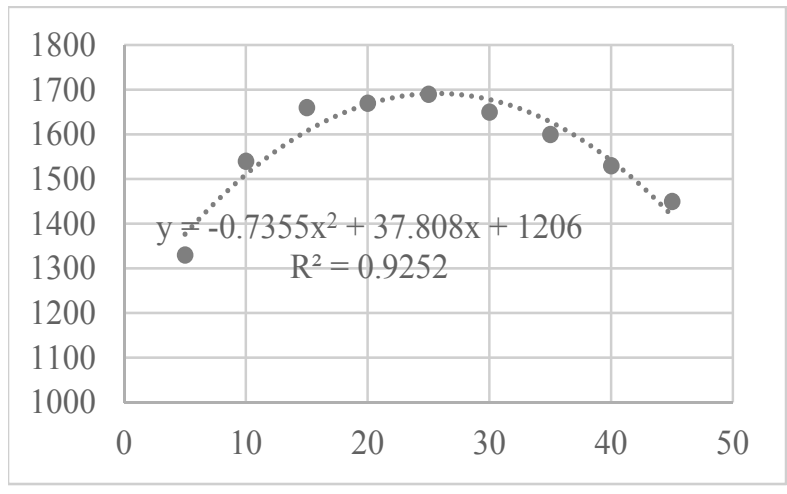

Fig 14 Maximum Bending Moment on raft versus Pile length for site I 


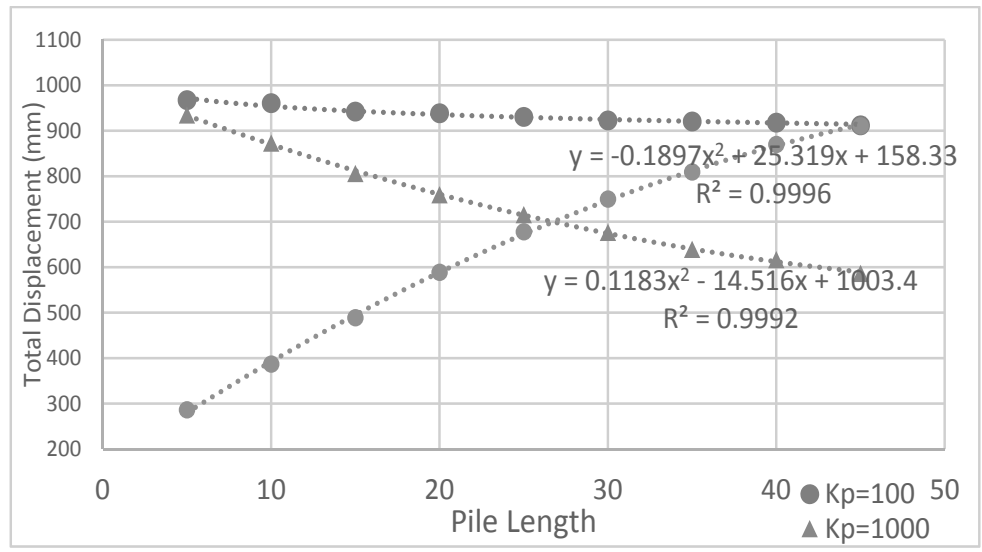

Fig 15 Displacement vs. pile length for site II for different compressibility of pile

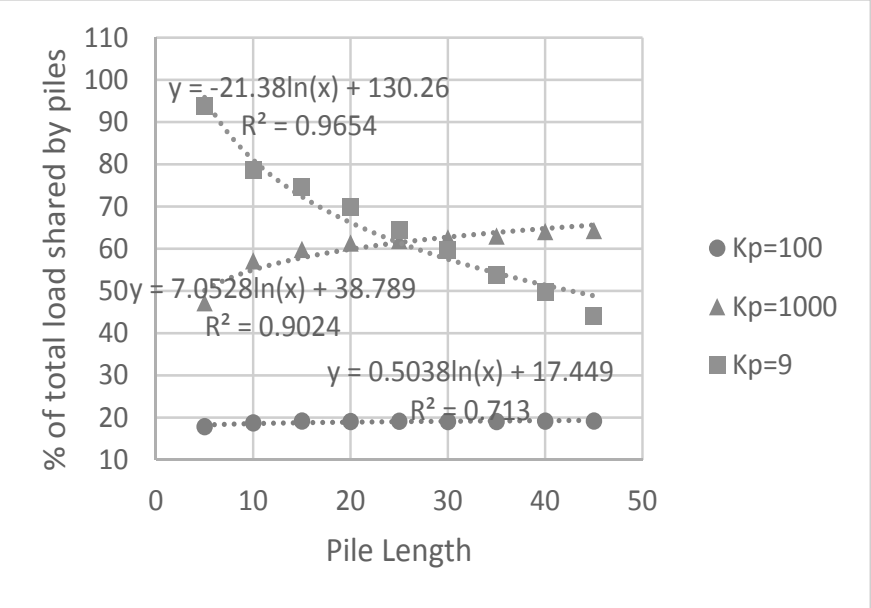

Fig 16 Percentage of total load carried by piles vs. pile length for site II for different compressibility condition of pile

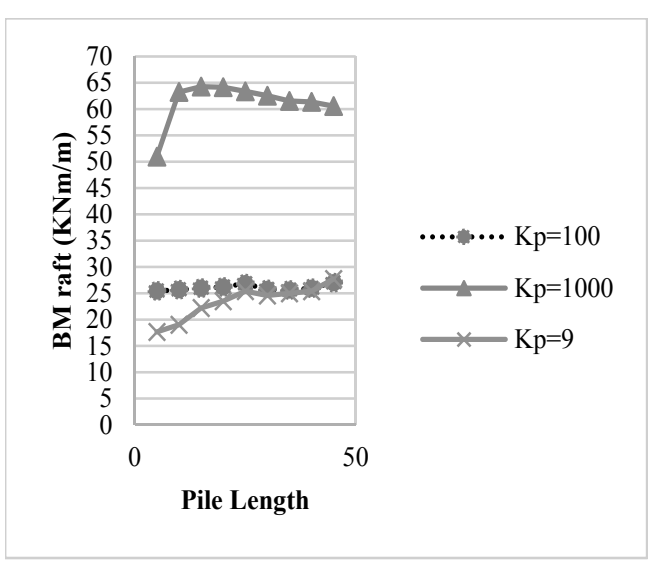

Fig 17 Maximum Bending Moment of raft vs. pile length for site II for different compressibility condition of pile.

For the soil data presented in Table 5 and Kst $=0.1$ and $\mathrm{Kst}=0.001, \mathrm{Kp}=100,1000$ and 10000 maintaining equal spacing between the piles for each model and $\mathrm{L} / \mathrm{d}$ ratio of 50 where ' $\mathrm{L}$ ' is the length of raft and ' $\mathrm{d}$ ' is the thickness of raft, graphs have been generated for percentage of total load take by piles versus $\mathrm{s} / \mathrm{d}$ ratio. Where $\mathrm{s}$ is the spacing between piles. The curves obtained is compared with the curves provided by Brown and Weisner. The obtained result shows similar result.

Further ratio of maximum displacement for piled raft and non-piled raft has been plotted against number of piles by the researcher for different Kp values of 100, 1000 and 10000. While performing same set of analysis on 2D model which gives similar type of result with variation of about $12 \%$ which also adds on validating the result provided by Plaxis. 


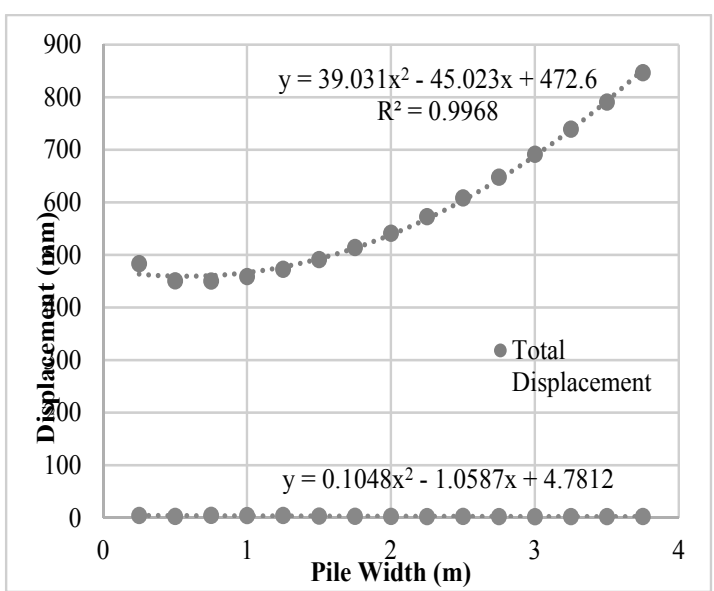

Figure 19 Displacement vs. pile width for site I

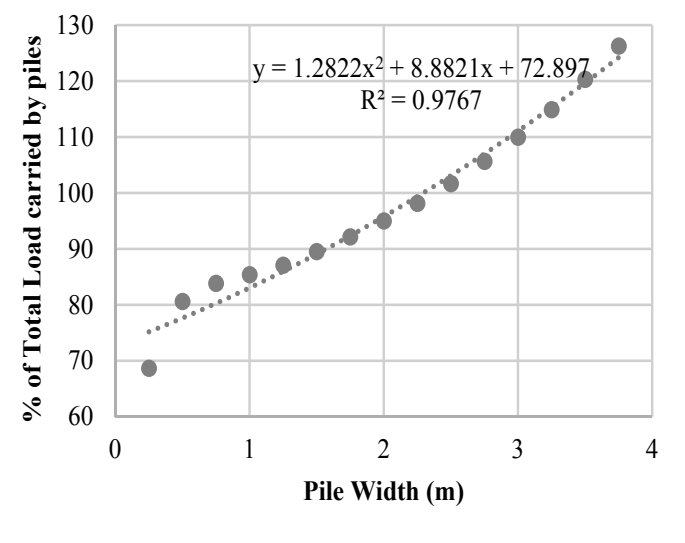

Figure 20 Percentage of total load carried by piles versus pile width Site I

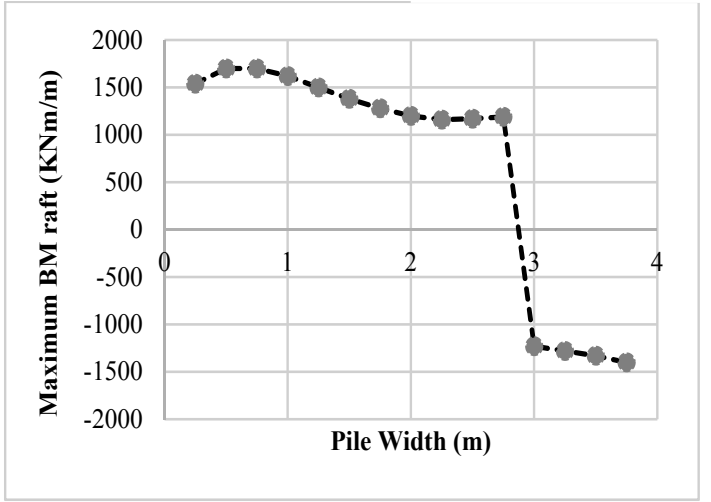

Figure 21 Maximum Bending moment of raft versus pile width Site I

Table 5 Soil parameter for analyzing(Brown and T.J.Wiesner, 1975) approach

\begin{tabular}{|c|c|c|c|c|c|}
\hline \multicolumn{7}{|c|}{ Soil parameters } \\
\hline General & Description & Parameters & Description & Interface & Description \\
\hline Identification & Clay & $\mathrm{E}$ & $3000 \mathrm{kN} / \mathrm{m}^{2}$ & $\mathrm{R}_{\text {inter }}$ & 0.7 \\
\hline $\begin{array}{c}\text { Material } \\
\text { model }\end{array}$ & $\begin{array}{c}\text { Mohr- } \\
\text { coulomb }\end{array}$ & $\square$ & 0.5 & & \\
\hline Material type & Drained & $\mathrm{c}$ & $30 \mathrm{kN} / \mathrm{m}^{2}$ & & \\
\hline$\square_{\text {unsat }}$ & $19 \mathrm{kN} / \mathrm{m}^{3}$ & $\square$ & 0 & & \\
\hline$\square_{\text {sat }}$ & $21 \mathrm{kN} / \mathrm{m}^{3}$ & $\square$ & 0 & & \\
\hline $\mathrm{K}_{\mathrm{x}}$ & 1 & & & & \\
\hline $\mathrm{K}_{\mathrm{y}}$ & 1 & & & & \\
\hline
\end{tabular}




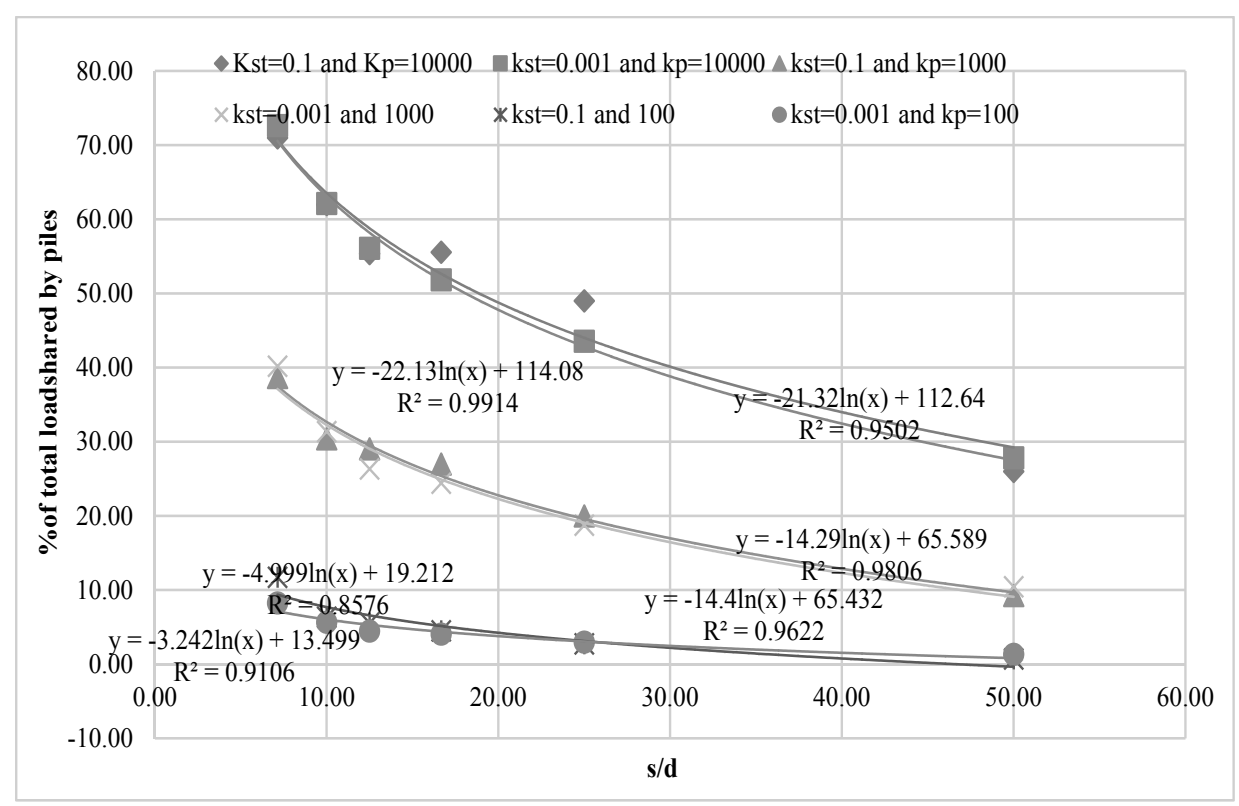

Fig 22 Percentage of Load carried by piles vs. s/d ratio for strip of different flexibility and pile of different compressibility. (Result obtained from plaxis2D)

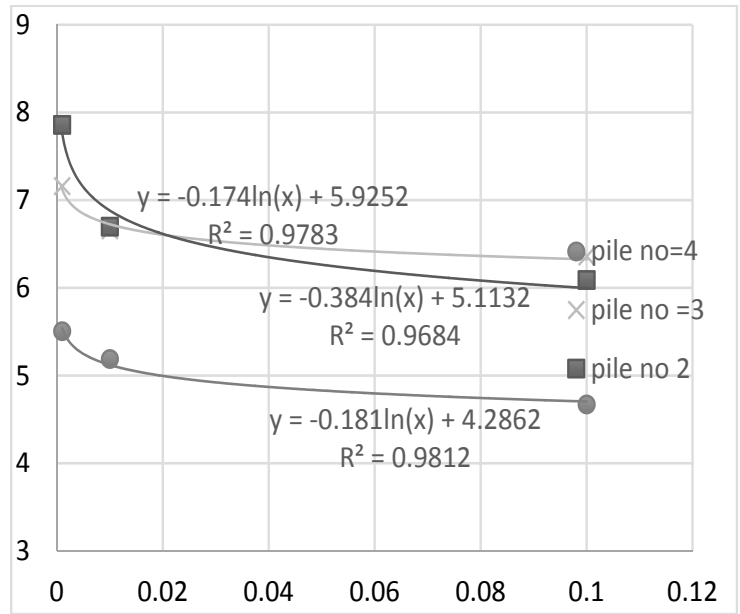

Fig 23[maximum displacement times $\left.\left(\mathrm{E}_{\mathrm{s}} / \mathrm{qB}\right)\right]$ versus ]

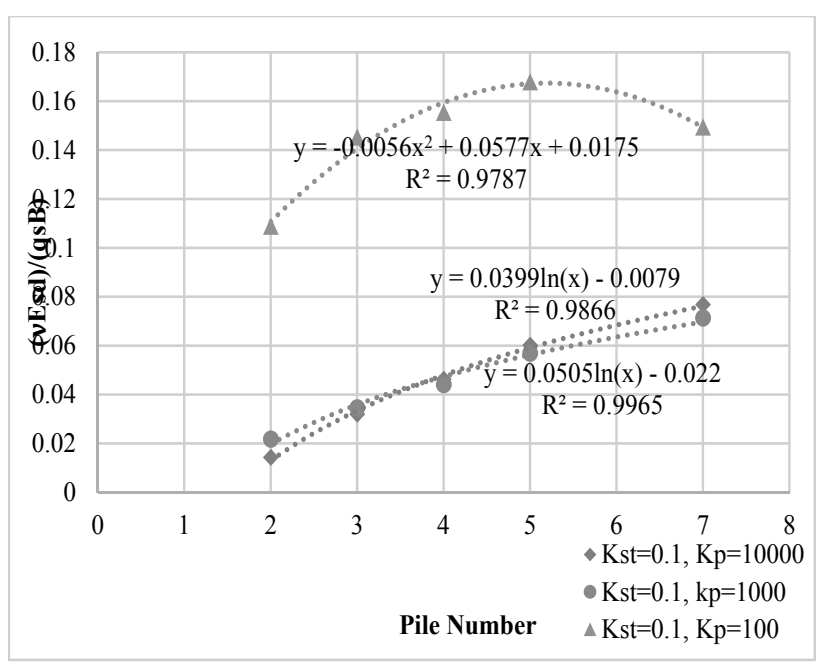

Fig 24 ( $\square$ Esd)/(qsB vs. Pile Number

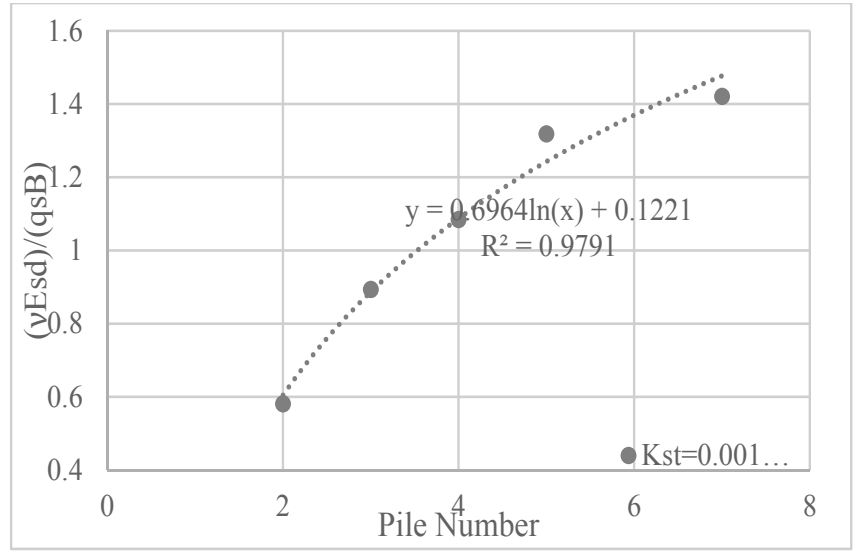

Fig 25 Differential settlement versus pile number

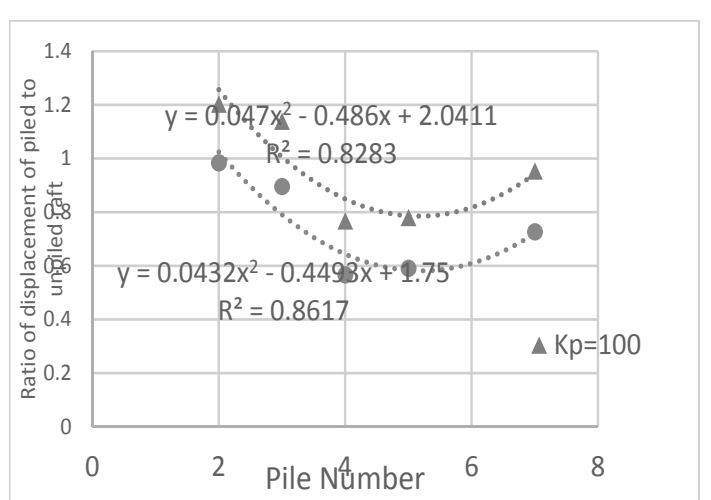

Fig 26 Displacement ratio of piled raft vs.unpiled raft 


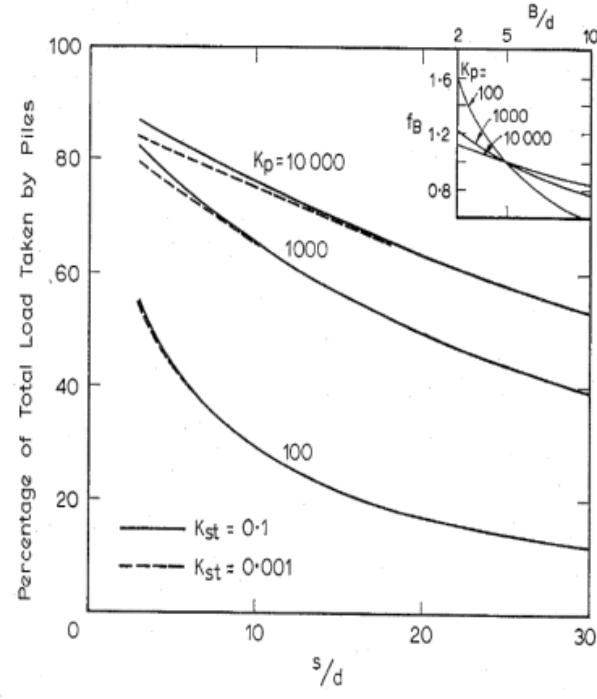

Fig 27Brown (1975) Percentage load carried by piles versus $\mathrm{s} / \mathrm{d}$ ratio

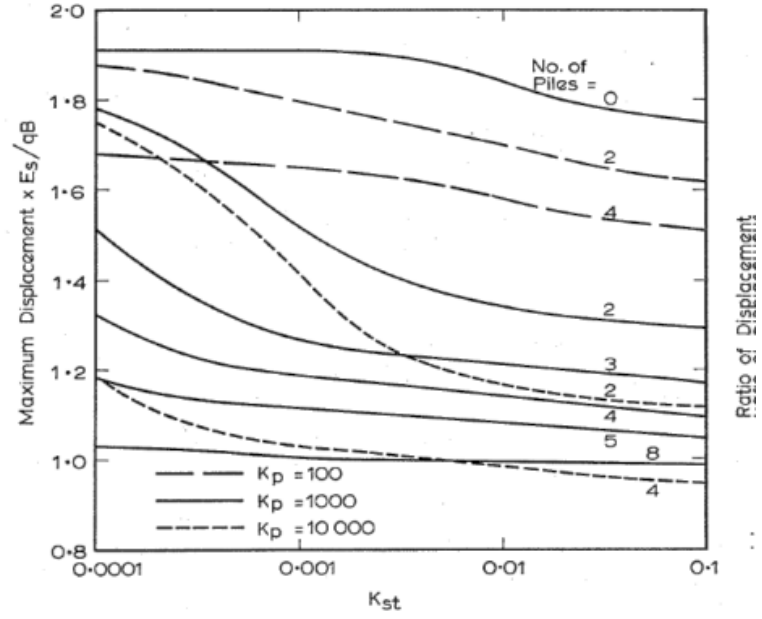

Fig 28 Displacement ratio of piled raft vs.unpiled raft

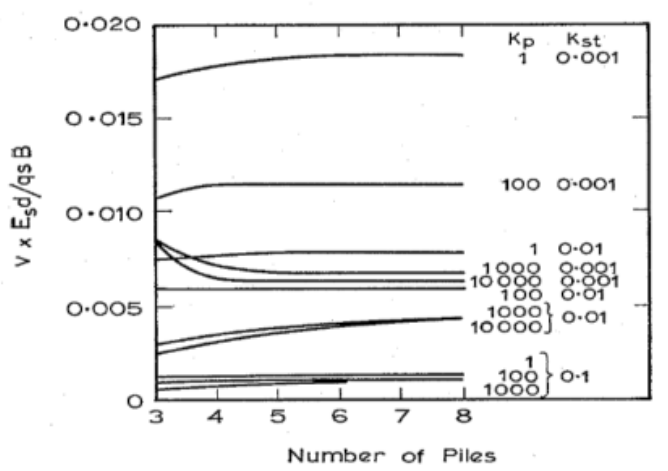

Fig 29 Brown (1975) Differential displacement for a footing

\section{Conclusion}

For unpiled raft, it is obtained that for variation of raft thickness, the differential settlement trend shows logarithmic decrement, total settlement shows exponential increment. With use of piles, total settlement and differential settlement can be further reduced. With increasing the number of piles such that spacing of piles are kept equal, it is obtained that total and differential settlement shows logarithmic decrement. The sagging moment increases with increase in pile number and pile load sharing increase logarithmically. Changing the length of piles shows logarithmic decrement of total and differential settlement, percentage load shared by piles and maximum bending moment on raft shows polynomial variation which increases up to certain length of pile and beyond that limit with increment of pile length shows decease in load sharing tendency and decrease in maximum bending moment of raft. The flexibility and compressibility of raft and piles governs the load sharing and settlement trend of foundation. For the load to be shared between raft and pile, the raft should be flexible. In case of rigid raft major portion of load is shared by raft. For flexible raft, if the pile is compressible then the variation of stress and displacement function with pile number, length and width of pile show contrasting result to the result shown by incompressible pile. 


\section{Recommendations}

The tool used over estimated result in case of settlement and underestimated result in case of load sharing behavior.Piled raft analyzed herein is analyzed by uniformly distributed loading which is not the actual case in practical field.Soil is considered homogeneous and effect of water table is not considered.Lateral loading is not considered for the analysis.Soil structure interaction could not be properly encountered. The interaction between pile and surrounding soil has been tried to incorporate through interface element

\section{Acknowledgement}

I wish to express my sincere appreciation to my supervisors Dr. Indra Prasad Acharya for his guidance and critical suggestion throughout the research work. I am thankful to the Department of Civil Engineering IOE, Pulchowk and Advanced College of Engineering, Kupondole for assisting me with the academics. I am also thankful to my colleagues from Geotechnical Engineering

\section{References}

1. Clancy, P. \& Randolph, M. F. (1993), "An approximate analysis procedure for piled raft foundations",Int. J. Numer. Anal, Meth. Geomech., 17: 849-869

2. Das, B.M., (2015), "Principle of Foundation Engineering", 7e, Cengage Leaning, Canada

3. Paulos, H.G. (2001), "Methods of Analysis of Piled Raft Foundations", International Society of Soil Mechanics and Geotechnical Engineering.

4. Randolph, M.F. (1994), "Design methods for pile groups and piled rafts", Proc., 13th Int. Conf. on Soil Mechanics and Foundation Engineering, Int. Society for Soil Mechanics and Foundation Engineering, 5, 61-82.

5. Burland, J. B. (1973), "Shaft friction of piles in clay: a simple fundamental approach", Ground Engineering, 6(3), 30 - 42.

6. Plaxis2D Reference Manual. (2008), Plaxis .

7. Fraser, R.A. \& Wardle, L.J. (1976),"Numerical Analysis of Rectangular Rafts on Layered Foundations",Geotechnique 26, No. 4, 613-630

8. Jean-Sebastien (2008), "FE-Analysis of piled and piled raft foundatins", LEBEA

9. P.T. Brown, T.J. Wiesner (1975),"Behavior of Uniformly Loaded Piled Strip Footing", Japanese Society of Soil Mechanics and Foundation Engineering, vol(15), No(4) 